\title{
Path Coefficient Analysis for Yield and Yield Contributing Traits in Rice (Oryza sativa L.) Genotypes
}

\author{
B. Kalyan ${ }^{1 *}$, K.V. Radha Krishna ${ }^{1}$ and L.V. Subba Rao ${ }^{2}$ \\ ${ }^{1}$ Department of Genetics and Plant Breeding, College of Agriculture, Rajendranagar, \\ PJTSAU, Hyderabad-500030, Telangana, India \\ ${ }^{2}$ Crop Improvement Section, Indian Institute of Rice Research, Rajendranagar, \\ Hyderabad-500030, Telangana, India \\ *Corresponding author
}

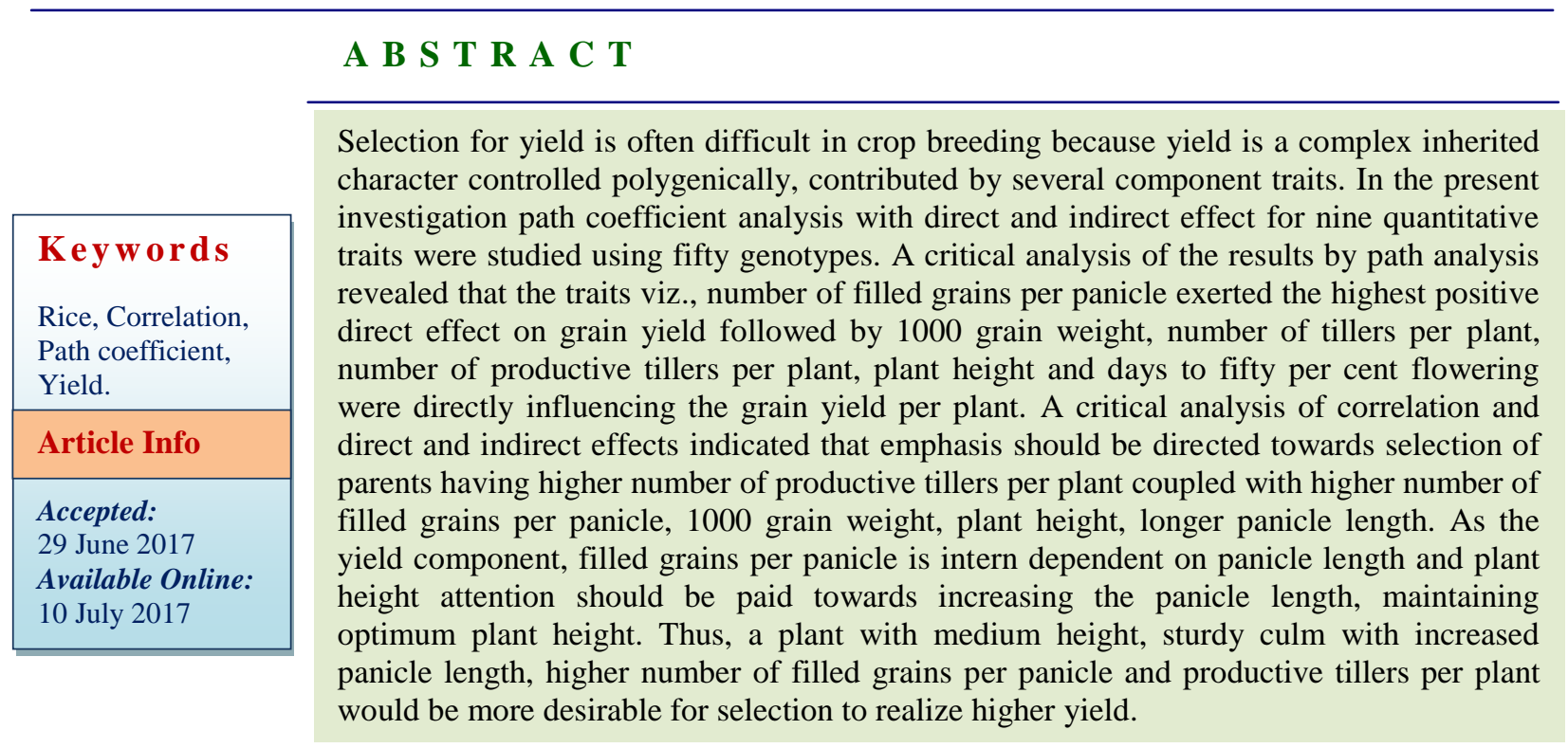

\section{Introduction}

The economic product of rice, exhibits complex genetics and is influenced by various yield contributing characters. These yield contributing characters are further interrelated. The study of relationship among quantitative traits is important for assessing the feasibility of joint selection for two or more traits instead of selection of secondary traits on genetic gain for the primary trait under consideration. Path coefficient analysis is a tool which permits the partitioning of the correlation coefficient into its components, one component being the path coefficient that measures the direct effect of a predictor variable upon its response variable; the second component being the indirect effect of a predictor variable on the response variable through other predictor variables. In agriculture, path analysis has been used by plant breeders to assist in identifying traits that are useful as selection criteria to improve crop yield. The association of different component characters among themselves and with yield is quite important for devising an 
efficient selection criterion for yield. The total correlation between yield and component characters may be some times misleading, as it might be an over-estimate or under-estimate because of its association with other characters. Hence, indirect selection by correlated response may not be some times fruitful. When many characters are affecting a given character, splitting the total correlation into direct and indirect effects of cause as devised by Wright (1921) would give more meaningful interpretation to the cause of association between the dependent variable like yield and independent variables like yield components. This kind of information will be helpful in formulating the selection criteria, indicating the selection for these characters is likely to bring about on overall improvement in single plant yield directly.

Thus, present study was undertaken to describe the character association and contribution of various yield influencing traits to establish appropriate plant attributes for selection to improve the yield of rice breeding lines.

\section{Materials and Methods}

The experimental material consisted of 70 genotypes of rice which were planted during Kharif 2014 at Directorate of Rice Research Farm, ICRISAT Campus, Patancheru, Hyderabad. These test genotypes were tested in the field in a randomized block design with three replications adopting a spacing of $20 \mathrm{~cm}$ within the row and $30 \mathrm{~cm}$ between the rows. The recommended agronomic practices were followed to raise a healthy crop.

Five plants were selected randomly and tagged from each genotype per replication and observations were recorded on Days to $50 \%$ Flowering, Plant Height $(\mathrm{cm})$, Number of tillers/ plant, Number of productive tillers/plant, Panicle length $(\mathrm{cm})$, Number of filled grains/panicle, Days to maturity, Grain yield/plant(g) and 1000 grain weight $(\mathrm{g})$. The mean of three replications was used for statistical analysis to compute correlation coefficients, and path coefficient analysis with direct and indirect effect on yield.

\section{Results and Discussion}

Based on the data recorded on the genotypes in the present investigation, the genotypic and phenotypic correlations were estimated to determine direct and indirect effects of yield and yield contributing characters. The present results of phenotypic path coefficient of yield and yield contributing characters discussed here under which were presented in table 1 and figures 1 and 2 .

The days to 50 per cent flowering had direct phenotypic positive effect $(-0.0180)$ on grain yield and the correlation between days to 50 per cent flowering and grain yield per plant was negative and non-significant (-0.1170).

The correlation was negative and nonsignificant mainly due to negative indirect effect through panicle length (-0.0025), number of tillers per plant (-0.0025), number of productive tillers per plant (-0.0025), number of filled grains per panicle (-0.0002). Similar result of direct positive effect of days to 50 per cent flowering on grain yield per plant was reported by Satish Chandra et al., (2009), Basavaraja et al., (2011), Padmaja et al., (2011) and Mohanty et al., (2012).

Plant height had phenotypic positive direct effect on grain yield per plant (0.0686) while the correlation of plant height with grain yield was positive and significant (0.4117). The correlation between plant height and grain yield was positive and significant mainly due to positive indirect effect contribution through number of tillers per plant (0.0204), number of productive tillers per plant (0.0189), 
panicle length (0.0186), number of filled grains per panicle (0.0299). The similar result reported by Madhavi Latha et al.,(2002), Sanker et al.,(2006), Basavaraja et al.,(2011) Mulugeta Seyoum et al.,(2012), Ravindra Babu et al., (2012), Nagaraju et al., (2013) and Rahman et al., (2014) also reported positive direct effect of plant height on grain yield per plant.

Total number of tillers per plant which exhibited a phenotypic positive direct effect on grain yield per plant (0.2848) while the correlation with grain yield per plant was also positive and significant (0.6214).

The correlation was positive and significant mainly due to positive indirect effect contribution through, plant height (0.0847), number of productive tillers per plant(0.2774), number of filled grain per panicle (0.0550) the similar result were reported by Singh et al.,(2002).

Productive tillers per plant which exhibited a phenotypic positive direct effect on grain yield per plant $(0.2480)$ while the correlation with grain yield per plant was also positive and significant (0.6215).

The correlation was positive and significant mainly due to positive indirect effect contribution through plant height (0.0682), number of tillers per plant $(0.2415)$, number of filled grains per panicle (0.0410). Sanker et al.,(2010), Basavaraja et al.,(2011), Padmaja et al.,(2011), Ravindra Babu et al.,(2012), Nagaraju et al., (2013) and Rao et al., (2014) reported positive direct effect of number of productive tillers per plant on grain yield per plant which are in accordance to the present results.

Panicle length had direct negative phenotypic effect (-0.0237) on grain yield per plant. Whereas the correlation was negative significant (-0.2091).The correlation was negative mainly due to negative indirect contribution through days to fifty percent flowering (-0.0050), plant height (-0.0064) and days of maturity (-0.0042). Similar results reported by Ganesan et al., (1997), Nayak et al., (2001), Madhavi Latha (2002), Satish Chandra et al., (2009), Pankaj et al., (2010) and Patel et al., (2014).

Number of filled grains per panicle had direct phenotypic positive effect $(0.5180)$ on grain yield per plant. Its correlation with grain yield per plant was also positive and significant (0.6056). The correlation between number of filled grains per panicle and grain yield per plant was positive and significant mainly due to positive indirect effect contribution through plant height (0.2229), number of productive tillers per plant (0.0845), number of tillers per plant (0.0986). Sanker et al.,(2006), Satish Chandra et al.,(2009), Mulugeta et al., (2012), Nagaraju et al., (2013) and Rao et al., (2014) reported similar results of positive direct effect of number of filled grains per panicle on grain yield per plant.

1000 grain weight had direct positive phenotypic effect on grain yield per plant $(0.4632)$ while its correlation with grain yield was positive significant (0.4011). The correlation between 1000 grain weight and grain yield per plant was positive is mainly due to very low negative indirect effect influence through days to fifty percent flowering (-0.0403), plant height (-0.0265), number of tillers per plant $(-0.0287)$, number of productive tillers per plant $(-0.0115)$, panicle length (-0.0599), number of filled grains per panicle $(-0.0327)$ and days to maturity $(-0.0117)$ on grain yield per plant. Similar results were reported by Sathish Chandra et al., (2009), Akhtar et al., (2011), Padmaja et al., (2011) and Rahman et al., (2014) negative direct effect of 1000 grain weight on grain yield per plant. 
Table.1 Phenotypic (P) and Genotypic (G) Path coefficient analysis of yield and yield contributing characters in rice

\begin{tabular}{|c|c|c|c|c|c|c|c|c|c|c|}
\hline Character & & $\begin{array}{c}\text { Days to } \\
50 \% \\
\text { Flowering }\end{array}$ & $\begin{array}{c}\text { Plant } \\
\text { height } \\
\text { (cm) }\end{array}$ & $\begin{array}{c}\text { No. of } \\
\text { tillers/ plant }\end{array}$ & $\begin{array}{c}\text { No of } \\
\text { Prod. } \\
\text { tillers / } \\
\text { Plant }\end{array}$ & $\begin{array}{c}\text { Panicle } \\
\text { Length } \\
\text { (cm) }\end{array}$ & $\begin{array}{c}\text { No. of } \\
\text { filled } \\
\text { grains/ } \\
\text { Panicle }\end{array}$ & $\begin{array}{l}\text { Days to } \\
\text { maturity }\end{array}$ & $\begin{array}{c}1000 \\
\text { Grain } \\
\text { weight } \\
\text { (g) }\end{array}$ & $\begin{array}{c}\text { Grain } \\
\text { yield/ } \\
\text { Plant (g) }\end{array}$ \\
\hline \multirow{2}{*}{$\begin{array}{l}\text { Days to } 50 \% \\
\text { flowering }\end{array}$} & $\mathbf{P}$ & 0.0180 & -0.0012 & -0.0025 & -0.0025 & 0.0038 & -0.0002 & 0.0151 & -0.0016 & -0.1170 \\
\hline & $\mathbf{G}$ & 0.0023 & -0.0002 & -0.0004 & -0.0004 & 0.0006 & 0.000 & 0.0022 & -0.0002 & -0.1319 \\
\hline \multirow{2}{*}{$\begin{array}{l}\text { Plant height } \\
(\mathrm{cm})\end{array}$} & $\mathbf{P}$ & -0.0047 & 0.0686 & 0.0204 & 0.0189 & 0.0186 & 0.0299 & -0.0147 & -0.0039 & $0.4117 * *$ \\
\hline & $\mathbf{G}$ & -0.0068 & 0.0773 & 0.0248 & 0.0224 & 0.0223 & 0.0350 & -0.0184 & -0.0055 & $0.4542 * *$ \\
\hline \multirow{2}{*}{$\begin{array}{l}\text { Number of } \\
\text { tillers / plant }\end{array}$} & $\mathbf{P}$ & -0.0388 & 0.0847 & 0.2848 & 0.2774 & -0.0667 & 0.0550 & -0.0676 & -0.0176 & $0.6214 * *$ \\
\hline & G & -0.0472 & 0.0964 & 0.3008 & 0.2970 & -0.0765 & 0.0611 & -0.0744 & -0.0208 & $0.6746 * *$ \\
\hline \multirow{2}{*}{$\begin{array}{l}\text { Number of } \\
\text { prod. tillers / }\end{array}$} & $\mathbf{P}$ & -0.0349 & 0.0682 & 0.2415 & 0.2480 & -0.0546 & 0.0410 & -0.0572 & -0.0062 & $0.6215^{* *}$ \\
\hline & $\mathbf{G}$ & -0.0436 & 0.0816 & 0.2776 & 0.2811 & -0.0659 & 0.0489 & -0.0697 & -0.0080 & $0.6770 * *$ \\
\hline \multirow{2}{*}{$\begin{array}{l}\text { Panicle length } \\
(\mathrm{cm})\end{array}$} & $\mathbf{P}$ & -0.0050 & -0.0064 & 0.0055 & 0.0052 & $-\mathbf{0 . 0 2 3 7}$ & 0.0012 & -0.0042 & 0.0031 & $-0.2091 * *$ \\
\hline & $\mathbf{G}$ & -0.0017 & -0.0020 & 0.0018 & 0.0016 & -0.0070 & 0.0004 & -0.0013 & 0.0009 & $-0.2189 * *$ \\
\hline \multirow{2}{*}{$\begin{array}{l}\text { Number of } \\
\text { filled }\end{array}$} & $\mathbf{P}$ & -0.0057 & 0.2229 & 0.0986 & 0.0845 & -0.0255 & 0.5180 & -0.0466 & -0.0361 & $0.6056^{* *}$ \\
\hline & $\mathbf{G}$ & -0.0072 & 0.2397 & 0.1074 & 0.0919 & -0.0290 & 0.5289 & -0.0528 & -0.0381 & $0.6370 * *$ \\
\hline \multirow{2}{*}{$\begin{array}{l}\text { Days to } \\
\text { maturity }\end{array}$} & $\mathbf{P}$ & -0.0057 & 0.0015 & 0.0016 & 0.0016 & -0.0012 & 0.0006 & -0.0068 & 0.0002 & $-0.1937^{*}$ \\
\hline & G & 0.0101 & -0.0025 & -0.0026 & -0.0026 & 0.0020 & -0.0010 & 0.0104 & -0.0002 & $-0.2143^{*}$ \\
\hline \multirow{2}{*}{$\begin{array}{l}1000 \text { Grain } \\
\text { Weight (g) }\end{array}$} & $\mathbf{P}$ & -0.0403 & -0.0265 & -0.0287 & -0.0115 & -0.0599 & -0.0327 & -0.0117 & 0.4632 & $0.4011 * *$ \\
\hline & $\mathbf{G}$ & -0.0450 & -0.0360 & -0.0348 & -0.0142 & -0.0653 & -0.0362 & -0.0104 & 0.5023 & $0.4304 * *$ \\
\hline
\end{tabular}


Fig.1 Genotypical path diagram for grain yield per plant (g)

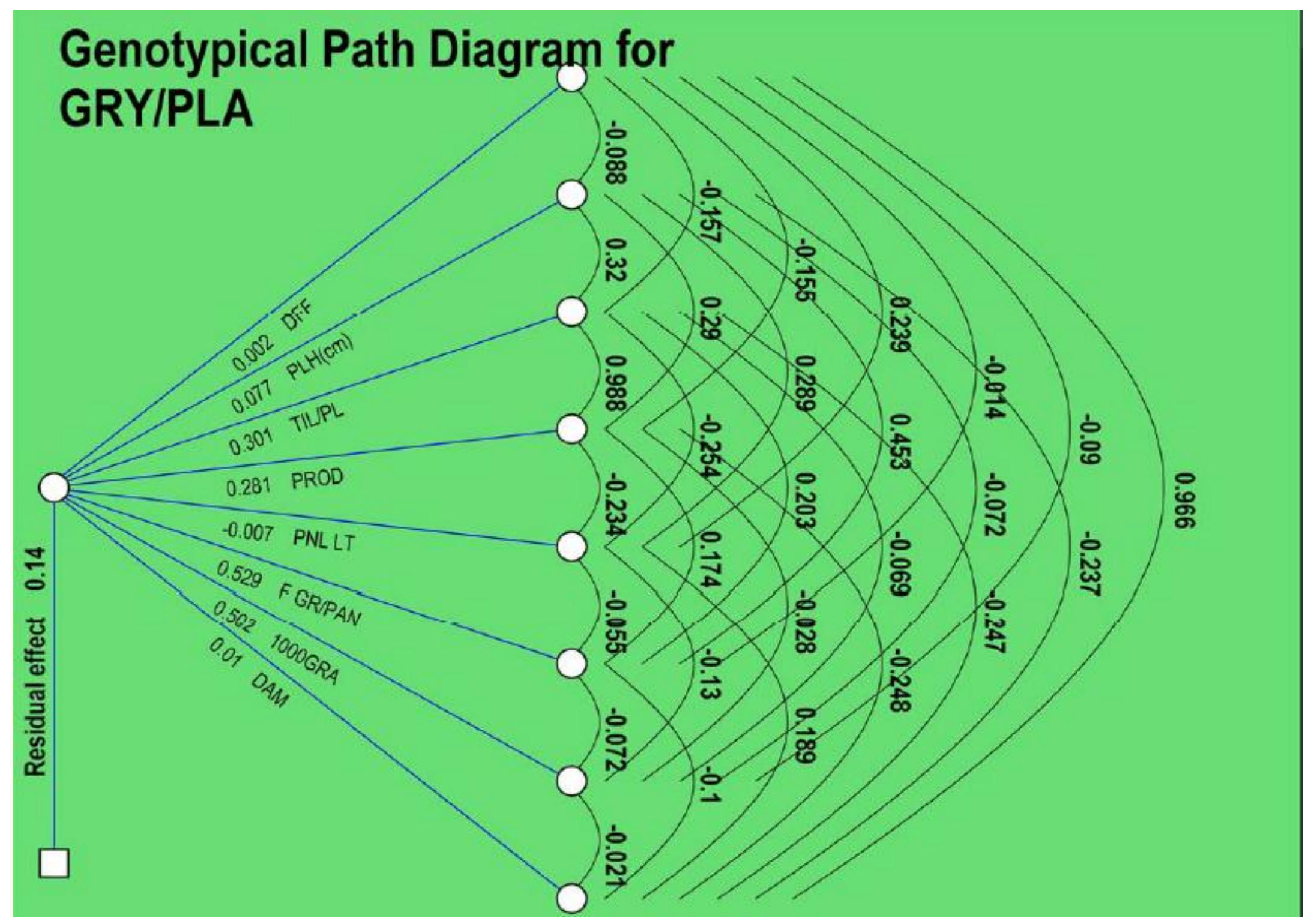


Fig.2 Phenotypical path diagram for grain yield per plant (g)

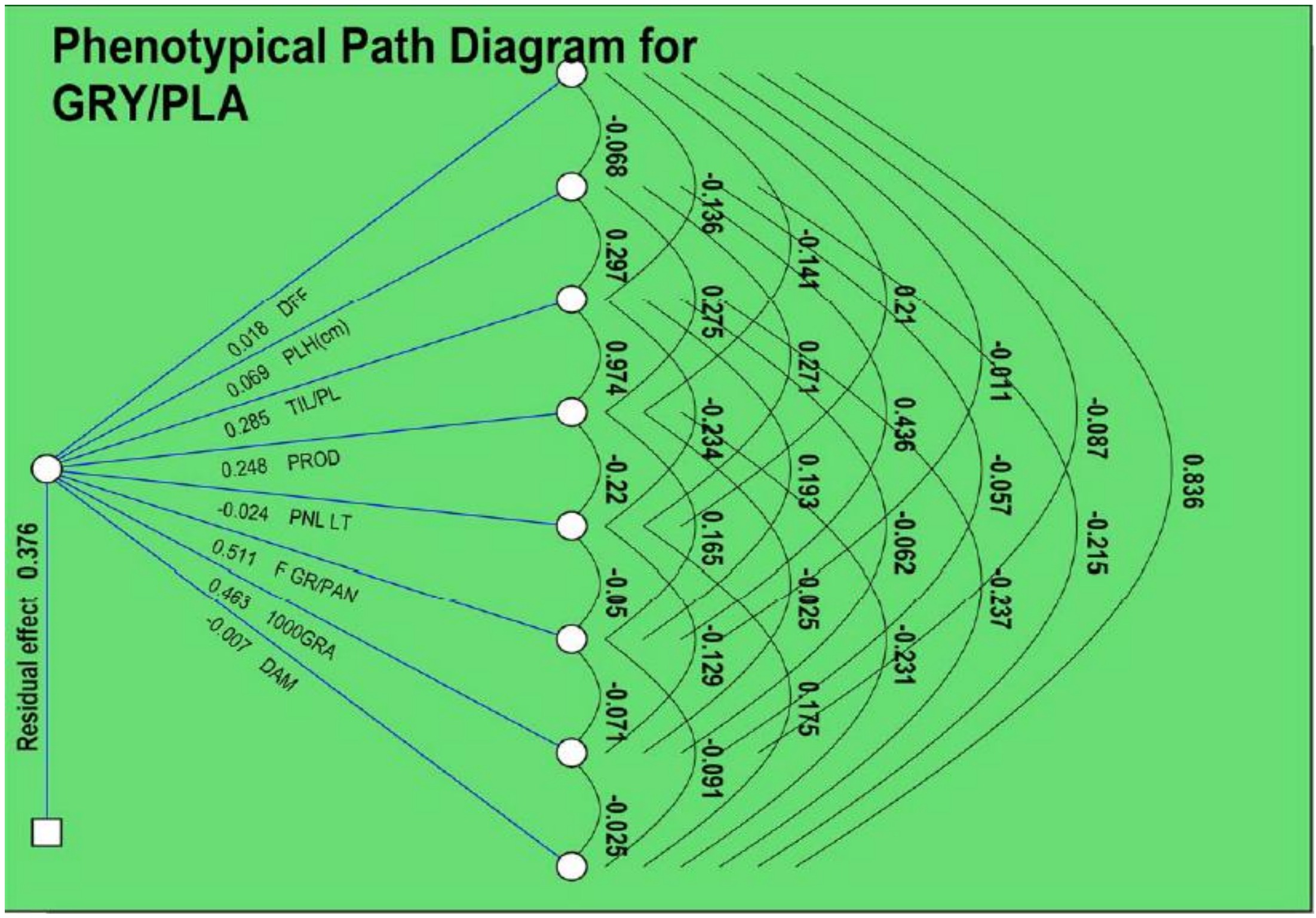


The day's maturity had direct phenotypic negative effect $(-0.0068)$ on grain yield and the correlation between days to maturity and grain yield per plant was negative and significant (-0.1937). The correlation was negative and significant mainly due to negative indirect effect through days to fifty percent flowering (-0.0057) and panicle length (-0.0012) and very low positive effects of other characters. Similar result of direct negative effect of days to maturity on grain yield per plant was reported by Pankaj Garge et al., (2010).

Path coefficient analysis revealed that number of filled grains per panicle exerted the highest positive direct effect on grain yield followed by 1000 grain weight, number of tillers per plant, number of productive tillers per plant, plant height and days to fifty per cent flowering. The negative direct effect was showed on grain yield by days to maturity, panicle length. These results were in conformity with Satish Chandra et al., (2009), Basavaraja et al., (2011), Padmaja et al., (2011), Mohanty et al., (2012) and Mulugeta et al., (2012) for days to 50 per cent flowering, Satish Chandra et al., (2009), Basavaraja et al., (2011), Padmaja et al., (2011), Mohanty et al., (2012) and Mulugeta et al., (2012) plant height, number of productive tillers per plant and panicle length. Mulugeta Seyoum et al., (2012), Nagaraju et al., (2013) and Rao et al., (2014) for number of filled grains per panicle. Satish Chandra et al., (2009), Yadav et al., (2011), Akhtar et al., (2011), Padmaja et al., (2011) and Rahman et al., (2014) for 1000 grain weight.

In conclusion, Path analysis revealed that number of filled grains per panicle, 1000 grain weight numbers of productive tillers per plant, number of tillers per plant, plant height are the most important characters which could be used as selection criteria for effective improvement on grain yield. Therefore, it is suggested that preference should be given to these characters in the selection programme to isolate superior lines with genetic potentiality for higher yield in rice genotypes.

\section{References}

Akhtar, N., Nazir, M. F., Rabnawaz, A., Mahmood, T., Safdar, M., Asif, M. E and Rehman, A. 2011. Estimation of Heritability, Correlation and Path Coefficient Analysis in Fine Grain Rice (Oryza sativa L.) The Journal of Animal \& Plant Sciences. 21(4): 660-664.

Basavaraja, T., Gangaprasad, S., Dhusyantha Kumar, B. M and Shilaja Hittlamani. 2011. Correlation and path analysis of yield and yield attributes in local rice cultivars (Oryza sativa L.). Electronic Journal of Plant Breeding. 2(4): 523526.

Ganesan, K., Wilfred Manuel, W., Vivekanandan, P and Arumugam. Pillai. 1997. Character association and path analysis in rice. Madras Agricultural Journal. 84 (10): 614-615.

Madhavilatha, L., Sekhar, M. R., Suneetha, Y and Srinivas, T. 2005. Genetic variability, correlation and path analysis for yield and quality traits in rice (Oryza sativa L.) Research on Crops. 6 (3): 527-537.

Mohanty, N.M., Sekhar, R., Reddy, D.M and Sudhakar, P. 2012. Genetic variability and character association of agromorphological and quality characters in rice.Oryza. 49 (2): 88-92.

Mulugeta Seyoum, Sentayehu Alamerew and Kassahun Bantte 2012. Genetic Variability, Heritability, Correlation Coefficient and Path Analysis for Yield and Yield Related Traits in Upland Rice (Oryza sativa L.) Journal of Plant Sciences. 7(1): 13-22.

Nagaraju, C., Sekhar, M.R., Reddy, K.H and Sudhakar, P. 2013. Correlation between 
traits and path analysis coefficient for grain yield and other components in rice (Oryza sativa L.) genotypes.International Journal of Applied Biology and Pharmaceutical Technology. 4 (3): 137-142.

Nayak, A. R., Chaudhary, D and Reddy, J. N. 2001. Correlation and path analysis in scented rice (Oryza sativa L). Indian Journal of Agricultural Research. 35(3): 186-189.

Padmaja, D., Radhika, K., Subba Rao, L.V and Padma, V. 2011. Correlation and path analysis in rice germplasm. Oryza.48 (1): 69-72.

Pankaj Garg., Pandey, D.P and Dhirendra singh. 2010. Correlation and Path Analysis for Yield and its Components in Rice (Oryza sativa L.). Crop Improvement. 37 (1): 46-51

Patel*, J.R., Saiyad, M.R., Prajapati, K.N., Patel, R.A and Bhavani R.T. 2014. Genetic variability and character association studies in rainfed upland rice (Oryza sativa L.) Electronic Journal of Plant Breeding. 5(3): 531- 537

Rahman, M.A., Hossain, M.S., Chowdhury*, I.F., Matin, M.A and Mehraj, H. 2014. Variability study of advanced fine rice with correlation, pathco-efficient analysis of yield and yield contributingcharacters. International journal of Applied Science and Biotechnology.Vol 2(3): 364-370.

Rao, V.T., Mohan, Y.C., Bhadru, D., Bharathi, D and Venkanna, V.
2014.Genetic variability and association analysis in rice.International Journal of Applied Biology and Pharmaceutical Technology.vol.5, issue 2 .

Ravindra Babu, V., Shreya, K., Kuldeep Singh Dangi, Usharani, G., Siva Shankar, A. 2012. Correlation and Path Analysis Studies in Popular Rice Hybrids of India. International Journal of Scientific and Research Publications. 2(3): $156-158$

Sankar, P. D., Sheeba, A and Anbumalarnaths, J. 2006. Variability and character association studies in rice (Oryza sativa L.). Agricultural Science Digest. 26(3): 182-184.

Satish Chandra, B., Dayakar Reddy, T., Ansari, N. A and Sudheer Kumar, S. 2009. Correlation and path analysis for yield and yield components in rice (Oryza sativa L.) Agricultural Science Digest. 29 (1): 45-47.

Singh, L., Singh, J.D and Sachan, N.S. 2002. Intercharacter association and path analysis in paddy. Annuals of Biology. 18(2): 125-128.

Wright, S. 1921. Correlation and causation. Journal of Agricultural Research. 20: 557-585.

Yadav, V.K., Yuvraj Singh, Sandeep Kumar Soni and Yadav, A. K. 2011. Genetic Divergence Analysis in Salt Tolerance Rice (Oryza sativa L.) Genotypes. Plant Archives. 11(2): 593-595.

\section{How to cite this article:}

Kalyan, B., K.V. Radha Krishna and Subba Rao, L.V. 2017. Path Coefficient Analysis for Yield and Yield Contributing Traits in Rice (Oryza sativa L.) Genotypes. Int.J.Curr.Microbiol.App.Sci. 6(7): 2680-2687. doi: https://doi.org/10.20546/ijcmas.2017.607.377 